\title{
moving encounters
}

ANN DESLANDES

\section{- I}

After twenty-four hours in aeroplanes between the continents of Australia and South America, I disembark at Porto Alegre's international terminal with a raging bladder infection. I am clutching the printout of an email from Jorge, giving me exact instructions for catching a cab from the airport to the 'activist house' where I will be staying for my first two weeks in Brazil. The state capital of Rio Grande do Sul in the south of Brazil, Porto Alegre is bounded by lush green farmland. The state is the birthplace of the Movimento Sem Terra (MST, an abbreviation of O Movimento dos Trabalhadores Rurais sem Terra-the Landless Rural Worker's Movement) and the city has been governed by the left-wing Partido Trabalhista (PT, the Worker's Party) for the past nine years. The Porto-Alegrense PT is lauded in overseas left-wing circles for their direct democracy model of 'participatory budgeting'1 and, along with the MST, have been prominent participants in the annual World Social Forum. The forum has been held in Porto Alegre four times since 2000, and is advanced as a talkfest slash party that annually generates the affective and strategic momentum for oppositionally poising the global justice movement in the tracts of empire and capital.

The only tract that I am focused on at this point is of the urinary variety, and I walk around the airport until I find a farmácia full of unfamiliar brand logos. I ask the smiling young men behind the counter if they have a product that I know of called 'Ural' (doesn't globalisation mean the hegemonic transnational proliferation of western pharmaceuticals?). I am speaking Portuguese, but they don't understand me. 'I think I have a bladder infection...', I add hopefully. They still don't understand me. I walk out. The burning in my abdomen will have to wait. I exit to a wall of cabs 
and their spruiking drivers, get into one and give weak directions. The driver looks it up in his directory and we speed off.

From the moment of my arrival in Brazil ${ }^{2}$ I find that I am no longer executing an academic project as the 'student researcher' who appears in my proposal to the university ethics committee. Instead I am a tongue-tied object of curiosity. I came to Brazil to interrogate 'others' about 'their' difference, but this was regularly undone by moments of encounter that highlighted my own difference. As such, my objective in this essay is not to provide a thorough, evidence-based argument about the MST, or about any aspects of Brazilian culture. The 'strange encounters'3 with people associated with my research are used here primarily to highlight matters of researcher positionality in ethnography, and to query first world activist constructions of the global justice movement. ${ }^{4}$

As any global justice movement activist will tell you, neoliberalism and economic globalisation are terms and conditions that define the contemporary social, political and cultural world landscape. They are axiomatic to the job insecurity, unprecedented wealth inequality and xenophobic social policy currently sweeping first world countries. The economic instability, warmongering and shrinkage of social welfare provisions attendant on these conditions obviously have an adverse effect on people marginal to these conditions-including dissident activists and intellectuals. In this sense, the squatters, dumpster-divers, protestors of immigration detention and anti-corporatists who have publicly countered these atmospheres in recent first world history are responding with justifiable outrage and insurgence with their activist work in the twenty-first century. ${ }^{5}$ This work has commonly aspired to a non-hierarchical, decentralised organisation which transcends the state as a regulating mechanism and acts in solidarity with those oppressed by neoliberal globalisation. ${ }^{6}$

The position of privilege occupied by these first world dissidents—relative to third world experiences of endemic poverty, war, mass unemployment, famine, chronic displacement and other circumstances both created and exacerbated by the liberalisation and globalisation of markets and the roll back of global social safety nets-is a stark point of reflection for activists. ${ }^{7}$ In recent years this has been well illustrated in my immediate locale of inner-city Sydney. For example, in 2002 and 2004 a group of tertiary-educated, urban-living, predominantly white Anglo, income-bearing activists occupied vacant, privately owned suburban buildings and in so doing invoked a direct alliance with groups like the indigenous Mayan Zapatistas in Mexico, who protest free trade and establish autonomous communities while fighting off the national military in the Lacandon jungle amid food, housing and water 
shortages. ${ }^{8}$ What struck me then was how the rhetoric of solidarity can also solidify the difference between locales.

On a train ride between suburbs in São Paulo, I think about how it is impossible to escape from people selling you things here. Everywhere I go there is someone in my face trying to get me to buy some disposable, toxic item: plastic hair clips, sweets, crisps, toys, cassettes, gum. I think about how, in first world activism, neoliberal globalisation is criticised for putting ads in our face all the time, from TV programs to billboards to the backs of toilet doors. ${ }^{9}$ In São Paulo, the people selling the proverbial moment's gratification on the street, on the trains, at the bus stop-everywhere there is space, everything for sale-seem a kind of tragicomic imitation of this, as much as it is the 'real' face of neoliberal globalisation.

So in designing my doctoral research at the end of 2004, I pursued the task of exploring the differences between the various locales acting under the rubric of the global justice movement- the comparative cultural and material circumstances which bracket the activist actions that take place here. I wanted to think through the activist alliance between first and third world locales as a power relationship stamped with endemic inequalities. This has, of course, been a preoccupation of modern international social movements that pre-date the global justice movement: from the Communist International to the international labour movement to the transnational feminist movements; and remains a commensurate preoccupation of academic writing in the humanities.

Brazil's Movimento sem Terra, the MST, is firmly implicated in this task. As a peasant movement with transnational connections, the MST forms part of the 'livelihood activism' from which the global justice movement draws much of its legitimacy. It is the most globally recognised of a number of landless peasant farmer's movements in Brazil. Landlessness is a material and social condition demonstrable of a country that is widely cited as containing the most unequal distribution of land in the world. ${ }^{10}$ The vast majority of land is largely comprised of what the MST call latifundio, wealthy inherited estates (their owners are latifundiário) and agricultural corporations (agronegócios). This state of affairs is linked to agricultural policy reform in recent years (following the end of a twenty-year military dictatorship in 1985) which, while it has included the addition of a reinforced social 'right to land' under the Brazilian constitution of 1988 and a program of land expropriation under state and federal government supervision, has been under-enforced and has not delivered a substantial redistribution of land and resources. ${ }^{11}$ Hence the landless activism typified by the MST, who have 
forcibly occupied disused, fertile land in twenty-three out of the twenty-seven Brazilian states, to form approximately two thousand assentamentos (settlements) to which they have gained land title. At the time of writing it is estimated that 180,000 families nationally are camped out (on acampamentos, or encampments) in various regions awaiting the same recognition. ${ }^{12}$

On the outskirts of the town of Teodoro Sampaio is an assentamento coordinating office for the Pontal do Paranapanema region. ${ }^{13}$ On my first day visiting there, José and Paulo offer to take me for a drive through the assentamentos. I recall my solemn promise to the university ethics committee (and my parents) about not getting into any 'strange' cars while conducting Official University Research, and get into Paulo's car. We drive at full speed through the countryside with José and Paulo yelling things at me at the same time:

'This is a sem-terra car-no documents, no frills!'

'Did you know that 99 per cent of the land in Brazil is owned by 1 per cent of the people?!'

'The latifundiário lives there- he has so many million hectares, it's so unjust!'

'And he has pistoleiros [pistol-men; that is, hired guns], with lots of pistols!' Paulo grins and cocks his thumb and forefinger.

'Before the assentamento I was hungry, miserable, now - I am happy, I have enough to eat, life is good!'

They are so proud. 'This is our land, all our land-we were camped out here, and here, and now we have a home, a good life.'

The MST assentamentos are legendary as examples of self-contained, liberatory collective endeavours. Not only are individual families housed on the assentamentos, they also establish cooperative farms and health clinics, and schools for children that use pedagogical frameworks designed by radical Brazilian educator and social theorist Paulo Freire (1921-1997). ${ }^{14}$ The MST operates a number of small companies that produce organic food and seeds for sale on the domestic and global market; facilitated by their membership of the global small farmers' network Via Campesina, another iconic player in the global justice movement. Further, in the tradition of many 1980s and 1990s 'new social movements' (responding to the political climate for activism, which saw a shift away from 'old left' vanguard organisations towards decentralised movements and issue-based or identity-based campaigning), ${ }^{15}$ the MST actively promotes their autonomy from established institutions, including the Catholic Church and the Worker's Party, despite their strong affiliations to both.

Ideologically, the movement is driven by socialist principles of cooperative land ownership and centralised democracy; expansion and propagation of the movement is carried out 
at the grassroots level by militantes (militants) who are trained in 'activist formation' and Latin American socialist ideology and who aim to recruit families from poor rural towns, urban shanty towns and inner-city favelas (like slums or ghettos) to participate in land occupations. ${ }^{16}$

Much of the scholarship and polemical material in English regarding the global justice movement presents the MST as leaders and icons of the movement in some way. ${ }^{17}$ The MST particularly appears as a major player in the World Social Fora, with their participation and leadership often cited as examples of the movement being 'led' by activist groups in the third world. In fact, for the first world scholars and activists who put together the collection We Are Everywhere under the name of 'Notes from Nowhere', the particular struggles of landless Brazilian farming families and refugees in Australian detention centres are expired in the same breath against 'neoliberalism': an ideology which is linked to the maldistribution of arable land in Brazil as well as the repression experienced by refugees through immigration detention policies in Australia:

Refugees detained in the Australian desert tear down prison fences, and are secreted to safety by supporters outside. The poor, rural landless of Brazil cut the wire that keeps them out of vast uncultivated plantations and swarm onto the properties of rich, absentee landlords, claim the land, create settlements, and begin to farm. ${ }^{18}$

What interested me about this representative passage was how costly, in comparison to the Australian 'supporters' at Woomera, the actions of the MST are to personal life and liberty under Brazil's sociopolitical configurations (which included the military dictatorship between 1964 and 1985, and that still affords power to the latifundiário). And then, how might the comparative risks impact on the relationship inscribed by Notes from Nowhere? ${ }^{19}$ Even a cursory glance at news reports as well as the polemic and scholarship shows that, in carrying out their activism, MST members are at risk of violence and murder from local police (who are a military corps, the Polícia Militar) and also from local militias, the pistoleiros hired by the latifundiário. It is estimated that, since the movement's official inception in 1984, several hundred sem-terra (landless) ${ }^{20}$ and their allies have been assassinated, including an infamous massacre of twenty-one sem-terra in 1996 by military police in the state of Pará. ${ }^{21}$ Furthermore, the acampamentos are reliant on scarce food supplies, and are often camped out for months at a time. 'Not everyone stays', as one MST leader advised me: malnutrition, depression and related illnesses are common problems.

Within these textual coordinates, I proposed researching the MST as a case through which to consider the tensions surrounding relative privilege within global justice movement activism, and to redress the ethics of a solidarity between third and first world activists. As a particularly visible activist group operating in a third world locale, it seemed logical that 
the MST would aptly articulate the tensions and points of reflection within this power relationship.

- II

I am never quite sure how I came to be staying at the house in Porto Alegre. Earlier in the year, I wrote to Jorge, a Brazilian sociologist of social movements, and asked him if he knew of suitable accommodation in Porto Alegre. He wrote back saying he 'knew someone who knew someone' through an activist network who would be willing to accommodate me for a few weeks. I was to write to the householders and provide some information about myself, so that they would be satisfied that I was of an acceptable political persuasion. Convincing them of my ideological legitimacy was, according to Jorge, 'part of the game', and I 'was not to mention him' because they 'hate' him because of certain public criticisms he has made. I duly wrote to the householders and appraised them of my credentials: I was researching the MST as a case study for a thesis about global 'social justice' activism, and wanting to come to Porto Alegre to discuss my plans with MST scholars and allies. The householders wrote back and welcomed me. In the entire exchange, there had been no reference to any conversation that took place between Jorge's acquaintance and the householders, nor the correspondence between myself and Jorge. This did not change throughout my stay in the house, as though I had appeared through some kind of magic socialist porthole.

It was the process of explaining my project via email to Brazilian scholars and activist contacts that, in revealing the complex politics around the MST, started to destabilise the fundamental premises of my research plan. Many contacts were unquestioning in their support for the movement and glad to assist me with my project. Conversely, Jorge cautioned me that the MST was not a social movement so much as a heavily ideologised political organisation that had exiled people simply for making criticisms. Another academic contact, Pedro, simply said he didn't understand my project's reference to practices of autonomy and decentralisation, because these practices did not exist within the MST. A Brazilian activist living in Sydney, João, also noted how heavily bureaucratised the movement was and suggested I focus on more contemporary activist projects like the Movimento dos Trabalhadores sem Teto (the Roofless Worker's Movement, an urban squatting movement) or newer, more anarchistic landless groups. In particular, this sense of there being an unspoken authoritarianism-both within the MST and within external accounts of the MST—only increased the more I inquired into the movement while I was in Brazil. 
My contact in the country town of Presidente Prudente is a graduate student called Wilson, who has recommended that I stay in a particular hotel. I walk into a reception area to the stares of a large group of men standing around together. One of them asks me if he can help, and we negotiate a room upstairs. Coming back down the stairs, I remain an object of this group's unmitigated gaze. I feel unnerved. I can't see any women around. I ring Wilson on the public phone and say thinly; 'I'm not sure if this place is safe — and there aren't any women here'. He laughs and says, 'It is safe, there are women. I wouldn't recommend anywhere unsafe.'

On my final day in Prudente I meet with a Professor Luiz Salgado, who has ten minutes available for meeting with me. He asks me to tell him about my research and I nearly implode. We've been having an email exchange for the entire year. And he wants to know what my research is about! Why do I want to speak with settlers, he asks, do I want to ask them if they like being in the MST? I say that I am interested in the MST's international relationships, in how globalisation activists work together internationally. He nods and refers me to a number of publications on the MST that I have already acquired.

One needs to have a measure of pre-agreed contextual legitimacy in order to organise a collegiate meeting or conduct a research interview, and I seemed to possess little of this in the eyes of most of my contacts. For example, the majority of my contacts were men who addressed me as menina, little girl. I later realised that it is the norm for women of all sizes and ages to be addressed in this way and indeed to address each other like this-while it is perhaps implicitly sexist, it is not necessarily an overtly diminutising strategy. However, in the Australian social spaces that I customarily inhabit, 'little girl' is a very disrespectful way for a man to address a woman, especially in a collegiate academic context. In the time frame I had established (three to six months), I could not integrate these differences and engage with pre-arranged research contacts on mutual terms.

\section{- III}

Gazing on an abandoned acampamento between the towns of Presidente Prudente and Mirante do Paranapanema, the MST's trademark black polythene smouldering and fluttering in the dry wind; I was intrigued to see the site marked by a state road sign saying ACAMPAMENTOREDUZA VELOCIDADE (Acampamento: Reduce Speed), and took a photograph with my mind. It symbolised so well the state sanctioning of MST land occupation, which seemed substantially unconsidered in the global discourse of first world activists, longing as we do for a transcendant utopia beyond the state and all forms of domination. 
From the uber-urban cityscape of São Paulo to the idyllic provinciality of Bom Pastor assentamento, I was consistently reminded of the MST's quasi-legitimate position within the Brazilian state. ${ }^{22}$ Because the Brazilian constitution upholds the social right to land for its citizens, this right is used to defend occupation actions in the courts, and legally rationalises the occupation of disused arable land to be expropriated by order of the local authorities. It is chiefly through the tedium of the judicial process that land occupations go from the acampamento to the assentamento stage. As such, the MST can be said to use 'direct action' to 'force the hand' of local authorities. ${ }^{23}$

In negotiating a revolutionary program largely through the legal principles of the 'right to land' and 'unused land'; and the pressure points of social strata, the MST is delimited by governmental conditions as any local activism is (the familiar activist tension between 'revolution and reform'). ${ }^{24}$ As per the above quote from We Are Everywhere, global justice movement discourse tends to de-emphasise this, painting the MST as directly confronting and exploding the barriers of private property against complete opposition. Also notable is the tendency to portray the MST as a chiefly anticorporate movement, which is somewhat at odds with the movement's focus on occupying land owned tied up in the latifúndio rather than the agronegócio. Indeed, the legalities of invading land owned by agronegócios are prohibitive here.

I think it is likely that the reader of global justice movement texts 'knows' that such a binarised power/resistance equation is just an abstraction, but it remains a romanticised account that is cut off from Brazil's actual national policy framework and sociological constitution. An active de-romanticisation of the MST inflected my every day in Brazil: though politically antagonistic and subject to great risk, the MST is part of the Brazilian state, functioning similarly to the centralised and hierarchical non-government organisations rejected in first world global justice movement discourse. ${ }^{25}$ Sem-terra are so commonplace to be even dramatised in a telenovela (soap opera) between 1996 and 1997 called O Rei do Gado (The Cattle King); where a beautiful (female) sem-terra occupier and the (male) landowner fall in love. ${ }^{26}$

Pulling out of São Paulo, that monolithic smoggy city, the bus trammels past kilometres of shantytowns on the city's outskirts as I stare out the window. The shantytowns remind me of Leopold Podlashuc's research on Shack/Slum Dwellers International, especially his observation that such sites reflect the refuse of capitalism. ${ }^{27}$ This is particularly stark in São Paulo because it's right next to high levels of prosperity - the plastic bags from the hipermercado (enormous, underpopulated supermarkets) mere kilometres down the road are used to construct people's houses in the 'slums'. 
Hitting the capacious countryside with its verdant latifundios (or fazendas, large farms), it's clear where the longer life is to be had.

Brazil is no exception to the unrelentingly swift urbanisation process in motion throughout the third world, generated by global neo-liberalism. As Shack/Slum Dwellers International demonstrates, ${ }^{28}$ the contemporary third world is marked overtly by the outsourcing of factorybased labour from the first world, the continuing shift of jobs from rural to urban areas, and the expansion of cities to house global business interests. ${ }^{29}$ Globally, 'the countryside' is an endangered species. Many rural working families have moved to the shantytowns that I was passing on the way out of São Paulo. This is another claim that buttresses the global justice movement's legitimacy. Within this claim, apart from offering and achieving an unarguably better life for people in this situation, the MST represents the ultimate romantic dream for anti-capitalists: not only an 'autonomous', cooperative existence, but the reclaiming of life on the land from an aggressive corporate urbanisation process threatening to take over the entire globe.

- IV

\section{Segunda-feira (Monday)}

On my first day in Teodoro, I walk into a building full of people, ancient computers and red-andgreen logos. Isabel introduces me and says I have come here from Professor Luiz. Everyone nods and smiles, and Ana Maria offers to show me around, saying proudly: 'I am an MST militant'. She takes me around the back of the building and points out the fields rolling out from our vista in all directions. 'This is all MST land', she says proudly. We walk through a complex of tin sheds, huge trucks and grain processing machinery with Sabor do Campo ('flavour of the countryside') painted on the sides of the sheds. She tells me with a grin that much of it is funded by the federal land authority, INCRA. ${ }^{30}$

\section{Terça-feira (Tuesday)}

I am taking a tour of the Pontal with some geography students from a neighbouring state. Ana Maria shows us the herb garden that women look after behind the office, and the complex of sheds, trucks and machinery; stressing the misery and hunger of life in the favelas, before the sem-terra occupied and settled the land. She holds up the MST flag with her four-year-old son, and teaches us militant chants (Agrarian Reform-for a Brazil without latifundios! Men and women, together in permanent struggle!), including those taught to children, the sem-terrinhas (ittle landless). She reads from 'the book', which is like a Bible or a Maoist 'little red book'. The struggle of the MST draws on many people, she says, and she reads them out like the Catholic litany of the saints: she says a name and 
the audience must respond with 'present'. As she reads she becomes louder and more and more earnest, almost fanatical:

FLORESTAN FERNANDES!

Presente!

PAULO FREIRE!

Presente!

ANITA GARILBALDI!

Presente!

CHE GUEVARA!

Presente!

It seems an overly ideologised spectacle.

\section{Quarta-feira (Wednesday)}

I arrive with the geography students at the 'formation school' on São Bento assentamento. Walking up to the school building in the middle of thick scrub, I see rows of young men reading aloud: cadres. We sit around three men in MST tee-shirts and caps, and they drone on for two hours about 'the struggle'. It is a lecture-style briefing on the MST and its goal of establishing socialism. Later, they put on a dance party for the students and feed them pizza.

Upon reflection, I am reminded of Branford and Rocha's analysis of these disciplinarian tactics in the MST (121). As they suggest, it is possible to see the Marxist-Leninist ideology and militarised tactics as powerful narratives that creatively infuse the movement, rather than inflexible and repressive dogma. I remain reflective, though, when I think about the first world accounts of the MST and its recombination into a global discourse of autonomy and decentralisation; where first world activists tend to denounce such centralisation and militarisation as unwelcome remnants of an old school vanguardist activism. ${ }^{31}$

\section{Quinta-feira (Thursday)}

Paulo, João-Paulo and I pull into José's house on Bom Pastor assentamento. I am taken into the kitchen and introduced to Maria-'minha mulher', my woman-and three small children. Maria is making jam. We sit outside and Maria serves us coffee and disappears back into the kitchen. Later I see her silently picking herbs and watering the seedlings, the children playing around her, while her husband and his friends sit out the back and talk about the local government elections and acquiring a new truck for Bom Pastor.

At the end of the day I am driving along with José, Paulo and João-Paulo, and José starts asking me about women in Australia: yelled demands accompanied by intense stares.

Are you a feminist, or not? A strong feminist? Yes or no?

Does Australia have machismo? 
Does Australia have many modern women?

Do men beat their wives in Australia, or not?

Does your boyfriend beat you? (laughing)

Upon returning to Teodoro that night, I discover that the respected movement stalwart who spoke passionately about structural impoverishment in the rural north with me earlier in the day is the same man who tries to get me to come back to his hotel room and won't take não for an answer.

In 2000 the MST established the Setor de Gênero, 'Gender Sector' as a culmination of debate recognising that women in the movement, as in Brazilian society, are subject to a patriarchal culture dominated by machismo. The movement's gender discourse reveals women's subjection to sexual assault and domestic violence from men in Brazil, as well as advocating the right of women to have roles outside the home and equal rights to men (the 'modern woman'). ${ }^{32}$ As I was told by a woman I interviewed from the Setor, the ideal of gender equality is tied up with that of land equality. In Tetê Morais' 1987 film about the MST in Rio Grande do Sul, Terra para Rose (Land for Rose), the two are transmuted in the slogan 'liberte a terra, liberte a mulher!' (liberate the land, liberate the woman!): women's emancipation from the capitalist structure of land ownership is synonymous with their liberation from oppressive gender roles. ${ }^{33}$

Endemic machismo is scantily referred to in first world writing on the MST, particularly as something that may have an effect on relationships both within the movement and across borders. When it is spoken about, such as in Branford and Rocha, it is urgently portrayed as a phenomena that is present but waning (33). In view of this, I was not so surprised ${ }^{34}$ by the exposed 'myth' of a 'non-patriarchal movement' as by the 'myth-making' at work in the first world activist and academic discourse regarding the movement's exemplary gender equality, ${ }^{35}$ along with its extra-statist, non-hierarchical organising. Such objectification of the movement in both scholarship and polemic propels us towards the notion that the 'authentic oppressed' activism of the MST is leading the global justice movement to a more 'authentic' solidarity. In so doing, the specific, gendered, ideologised conditions of this solidarity's production remain concealed.

$-\mathrm{V}$

In the film Gadjo Dilo (Crazy Stranger), ${ }^{36}$ Stéphane goes to Romania because he has been captivated by the voice of a Roma singer called Nora Luca, recorded by his ethnographer father. He takes tapes and recording equipment with him in the hope of finding Roma women like her who he can record onto tape for taking back home with him to France. He spends 
some time living with a Roma community and towards the end of the film becomes sickened by his attempt to capture and commodify some cultural 'essence' expressed through the community's music, particularly when their living circumstances are so fraught with poverty and danger, and in preposterous juxtaposition to their 'ethnic value' as 'gypsy' entertainers to non-Roma communities. In the final scene, Stéphane ritualistically smashes and buries the tapes on which he has recorded their music.

I thought about Gadjo Dilo as I walked back to Teodoro after one day of visiting assentamentos on the Pontal. I was feeling fully the absurdity of trying to capture and directly translate 'activism in a poor country'. I decided to give up completely the notion of taping conversations with people. The next day, I gave my tape recorder to some MST school students who used it to record interviews with their fathers for a school assignment, while I looked on and smiled idiotically at people who served me coffee, mangoes and bananas.

In Gadjo Dilo, says Niobe Thompson, 'we are confronted with a refugee from our own, flawed cultures, seeking a sliver of truth in exotic and foreign surroundings, establishing contact with the "other" and preparing to return with his own pillaged treasure'. ${ }^{37}$ Stéphane's story is about how certain 'others' become fetishised-the 'stranger fetishism' conceptualised by Ahmed, where the stranger takes on 'bodily and linguistic integrity' and is divorced from her local, social, historical conditions of formation (5). This fetishism showed itself in my negotiation of the MST and its networks, as a tendency in global justice movement activism ${ }^{38}$ and which was at work in my own project of 'activist scholarship': I felt a certain thrill at being directed to the unmarked location of the MST central office, interrogated by American Airlines security guards about my research in Brazil when I left the continent, and transported in rickety cars and airplanes; even at being faced with the acres of dismal poverty. This perverse thrill came from the sense that these exposures to the third world 'realities' of risk might somehow authenticate me as an activist working against oppression, who had previously never left her comfortable first world environs ('He never fully recovered', sketches Judy Horacek, 'from the discovery that ASIO didn't have a file on him'). ${ }^{39}$ Like Stéphane looking to the Roma villagers for 'a sliver of truth', part of me had wanted to expose the 'real' global experience of rampant militarism and material desperation reflected in third world activism and cast it up to first world activists.

Indeed, in our discourse as activists, there is a nervy unease about our relative privilege: middle-class, educated, white; we can have a horror of not being appropriately aware of our privilege, aware of our option to recognise or not recognise our complicity in oppression. ${ }^{40}$ This leads to the (ultimately self-revealing) search for the 'authentic(ating) oppressed'. Perhaps we think it is possible to exorcise the fetish by experiencing its 'reality', but in so doing can reinscribe it in our eagerness for absolution. After leaving the Pontal region and travelling to Rio de Janeiro, I met a number of Brazilian scholars and activists in Rio who cemented 
this line of thinking. Gilberto, an activist involved in running a social centre in a favela, said that he is always amused by activists from England, Australia and the United States at the World Social Forum. 'They're all, you know, Viva Latin America!' he said wryly. 'Viva the poor people of Latin America!' He added, 'The Forum is just a spectacle ... only useful for networking. Did you know there were forty rapes reported at the last one?'41

$-\mathrm{VI}$

The capacity of the MST as a case study to articulate the tensions and points of reflection within the global justice movement's power relationships proved itself largely because of its exemplarity as third world activism being written about by first world activists and scholars. It is the movement's very 'visibility and aptness for articulation' 42 which itself already establishes the MST's as an accessible discourse for being co-opted by global relations of domination, including within a global movement dedicated to combating these relations. It is a condition of 'global' participation that, as Spivak puts it, 'the third world can enter the resistance program of an alliance politics directed against a "unified" repression only when it is confined to third world groups that are accessible to the first world' (288).

Such fetishism reflects the needs of first world scholars and activists for a utopian "new left' narrative, and/or an account which authenticates said activists and scholars as enacting a solidarity on the terms of 'the oppressed'. For building solidarity, this leads me to questions concerned more with first world privilege and complicity in oppression, as opposed to those of comparing and contrasting first and third world realities. This shift in questioning has also required, in my research, a shift of epistemological register; away from a saturated socialscientific case study and towards the deconstructing critique of interests provided by postcolonial feminism. Such displacements underscore my scholarly investigation of the global justice movement's ethics and politics of solidarity: I am moved, by these encounters, to write a movement of encounters.

ANN DEsLANDES is a PhD candidate in the Department of Gender and Cultural Studies at the University of Sydney. Her thesis is titled 'From Fetishism to Friendship: Politics and Ethics of Solidarity in (the) Global Justice Movement'. <ann.deslandes@gmail.com>

Thank you to Fiona Probyn-Rapsey, Adam Gall, Esther Berry, Jodi Frawley and the two anonymous reviewers for their valuable feedback regarding this essay. All remaining errors are mine. 
1. Municipality of Porto Alegre, Orçamento Participativo, <http://www2.portoalegre.rs.gov.br/ op>. See also, for example, Marion Gret and Yves Sintomer (trans. Stephen Wright), The Porto Alegre Experiment: Learning Lessons for Better Democracy, Zed Books, New York, 2005

2. I travelled in Brazil between August and November 2005 to conduct research on the MST for my doctoral thesis, in particular spending six weeks visiting in the region called the 'Pontal do Paranapanema' which sits on the Paranapanema river in the extreme west of São Paulo state.

3. Sara Ahmed, Strange Encounters: Embodied Others in Post-coloniality, Routledge, London, 2000. Further references are included within the text.

4. I am guided by Chandra Talpade Mohanty in my use of the terms 'first' and 'third' world. The terms are problematic and I use them reluctantly and critically. Still, as Mohanty puts it, 'the terms .. retain a political and explanatory value' in working with global inequalities in resources and power as I am in my research. See her 'Under Western Eyes Revisited: Feminist Solidarity Through Anticapitalist Struggles', Signs, vol. 28 no. 2, 2003, pp. 505-7

5. These counter-hegemonic practices are documented, for example, in Notes from Nowhere (eds), We Are Everywhere: The Irresistible Rise of Global Anti-capitalism, Verso, London, 2003; Amory Starr, Global Revolt: A Guide to the Movements Against Globalisation, Zed Books, London, 2005; Naomi Klein, Fences and Windows: Dispatches from the Front Line of the Globalisation Debate, Flamingo, London, 2002; Paul Kingsnorth, One No, Many Yeses: A Journey to the Heart of the Global Resistance Movement, Simon \& Schuster, London, 2003 and Tom Mertes, Movement of Movements: Is Another World Really Possible?, Verso, New York, 2003.

6. See for example, 'A Space Outside', A Space Outside: Active Interventions Within, November 2006 and 'Andrew', 'Shape Shifting', Desert Storm: Reflections on Woomera 2002, Desert Storm Editorial Collective (DSEC), 2002 $<$ http://www.antimedia.net/desertstorm/ shapes.shtml>

7. See for example Starr, pp. 95-7

8. In 2004 SCAN invited interested people to come and 'enjoy the zapatismo in the air', in the recently squatted space, saying that 'these kind of squats are part of an international matrix of squatting movements with histories of supporting worker, peasant, student and community uprisings critical of private property systems and government inequity'. They linked their inner city squatting project to local indigenous struggles, noting 'the prevention of indigenous communities from free movement within their own land' as 'national and international space becomes increasingly militarized and restricted'. From the SCAN website, now offline, last accessed 2006.

9. For example Kalle Lasn, Culture Jam: How to Reverse America's Suicidal Consumer Binge — and Why We Must, Quill, New York, 1999 and Naomi Klein, No Logo: Taking Aim at the Brand Bullies, Flamingo, London, 2000.

10. See for example Ariovaldo Umbelino de Oliveira, 'Barbárie e modernidade: o agronegócio e as transformações no campo'. Paper presented to the annual national meeting of the Pastoral Land Commission, Goiânia, Brazil, October 2003.

11. Specifically, the right is guaranteed under Title II, Chapter I, Article 5 of the Constitution of Brazil, which stipulates every citizen's right to property and that property should fulfil a social function, and which also provides for expropriation of land if necessary to achieve this. An agrarian reform law was passed in 1985, under which reform programs generally exist today

12. Paraphrased from Friends of the MST, 'About the MST', <http://www.mstbrazil.org>, San Franciso. Other landless movements in Brazil include the Movimento de Libertação dos Sem Terra (MLST); see also the Confederação Nacional de Trabalhadores na Agricultura, <http://www.contag.org.br>.

13. The region called the 'Pontal do Paranapanema' takes in twenty-two MST assentamentos and the towns of Teodoro Sampaio and Presidente Prudente (among others). The process of the MST's occupation of land in this area is detailed in Sue Branford and Jan Rocha, Cutting the Wire: The Story of the Landless Movement of Brazil, Latin America Bureau, London, 2002, pp. 55-61. Further references are included within the text.

14. See for example Paulo Freire, trans. Myra Bergman Ramos, Pedagogy of the Oppressed, Penguin, Middlesex, 1972

15. See for example André Drainville, Contesting Globalization: Space and Place in the World Economy, Routledge, London, 2004, p. 72.

16. The strong socialist ideological component (Marxist-Leninist in its orientation) has subjected the MST to some criticism within Brazil. Zander Navarro is the most prominent Brazilian critic in this vein. See for example: 'Mobilization Without Emancipation-the Social Struggles of the Landless in Brazil', in Boaventura de Sousa Santos, Another Production is Possible: Beyond the Capitalist Canon, Verso 2006, pp. 146-79.

17. For example: Notes from Nowhere, p. 21; Mertes, p. ix; Starr, pp. 123-4.

18. Notes from Nowhere, p. 122

19. For a related discussion of some of the ethical dilemmas for activists participating in detention 
centre protests such as at Woomera in 2002, see Desert Storm Editorial Collective, 2002, Damien Grenfell and Anna Trembath, 'No HorizonBaxter and Beyond: Where Now for the Refugee Movement?', Arena, Issue 65, June/July 2003 and Ann Deslandes and Debra King, 'Autonomous Activism and the Global Justice Movement: Aesthetic Reflexivity in Practice', Journal of Sociology, vol. 42, no. 3, 2006, pp. 317-18.

20. The MST uses the term sem-terra to refer to MST settlers. It is a term generally worn with great pride, as a signifier for a person who has participated in the education, occupation, encampment and settlement building processes of an MST assentamento.

21. MST, 'Quem Somos', <http://www.mst.org.br>

22. Miguel Carter, 'The MST and Democracy in Brazil', Working Paper, Centre for Brazilian Studies, University of Oxford, June 2005.

23. John Hammond, 'The MST and the Media: Competing Images of the Brazilian Landless Farmworker's Movement', Latin American Politics and Society, vol. 46, no. 4, 2004, pp. 61-90.

24. Sarah Maddison and Sean Scalmer, Activist Wisdom: Practical Knowledge and Creative Tension in Social Movements, UNSW Press, Sydney, 2006

25. See for example Eric Tang, 'The Non-Profit and the Autonomous Grassroots', Left Turn: Notes from the Global Intifada, <http://www.leftturn.org>

26. Carlos Araùjo et. al. (dirs), O Rei do Gado, Globo, 1996

27. Leopold Podlashuc, 'Deep Democracy: Horizontal Exchange and the Praxis of Poop', Cultural Studies Review, vol. 11, no. 2, September 2005.

28. Shack/Slum Dwellers International, $<$ http://www.sdinet.org>

29. See Mike Davis, Planet of Slums, Verso, London, 2006.

30. INCRA stands for Instituto Nacional por Colonização e Reforma Agraria, National Institute for Colonization and Agrarian Reform.

31. See sources quoted in footnote 5, particularly Starr, p. 22
32. A brief overview of the Gender Sector can be found in 'Mulher Sem Terra na luta por Reforma Agrária', <http://mst.org.br>. See also Miriam Abramovay and Maria das Graças Rua, Companheiras de luta ou coordenadoras de panelas? As relações de gênero nos assentamentos rurais, UNESCO, Brasilia, 2000. For discussion of some problems with anglophone use of the term 'machismo', see for example Lahoucine Ouzgane and Daniel Coleman, 'Postcolonial Masculinities: Introduction', Jouvert, vol. 2, no. 1, 1998, $<$ http://social.chass.ncsu.edu/jouvert/v2il/ int2l.htm>

33. Morais, Tetê (dir), Terra para Rose, 1987.

34. Ahmed, pp. 180-1.

35. For example, Kingsnorth p. 257

36. Tony Gatlif (dir), Gadjo Dilo, 1997 (French and Romanian with English subtitles). The title has also been translated from Romani as 'Crazy Foreigner'.

37. Niobe Thompson, 'Understanding the Gulf' in Central Europe Review, vol. 2, no. 41, 2000 at <http://www.cereview.org/00/4l/ kinoeye4l_thompson.html>.

38. Naomi Klein, for example, alludes to 'guilty lefties with a Latin America fetish', p. 209

39. Judy Horacek, Life on the Edge, Spinifex Press, Melbourne, 2002, p. 4

40. For example, Constantine Markides, 'Review of Wright and Wolford's "To Inherit the Earth", Land Research Action Network, 9 July 2004 $<$ http://www.landaction.org >: 'For those of us who feel helpless before the seemingly insoluble problems of the world, and for those of us who do not live in acute poverty with gunmen and military squads at our backs, understanding the accomplishments of movements like the MST should be both humbling and invigorating.'

41. See Ana Elena Obando, 'Sexism in the World Social Forum: Is Another World Possible?', Women's Human Rights Net, February 2005 <http://www.whrnet.org/docs/issuesexism wsf.html>.

42. See pp. 155-6 in this article. 